\title{
GRAMMATIKAKATEGOORIATE SEKUNDAARSEST KASUTUSEST: VENE JA EESTI AJAVORMID
}

\author{
Sirje Kupp-Sazonov, Irina Külmoja
}

\begin{abstract}
Ülevaade. Tänapäeva keeleteaduses üha aktuaalsemad tüpoloogiaja kontrastiivuuringud vajavad ühtlustatud grammatikakategooriate süsteeme ning üheselt mõistetavat terminoloogiat. Eesti keele grammatiliste vormide põhitähendusi on uuritud põhjalikult, kuid sekundaartähendused vajavad veel tähelepanu. Artiklis kõrvutatakse mõningate eesti ja vene keele grammatikakategooriate esinemist ülekantud tähenduses, et näidata selliste kasutusviiside olulisust keele uurimise, õpetamise ning samuti tõlketeooria ja -praktika seisukohast. Põhitähelepanu on ajavormidel. Artikli teises pooles üritatakse sekundaartähendusi tähistavaid oskuskeelendeid analüüsides leida sobivaimaid variante eesti keele grammatika jaoks.*
\end{abstract}

Võtmesõnad: metafoor, ajakategooria, terminoloogia, eesti keel, vene keel

\section{Sissejuhatus}

Keeletüpoloogia ja kontrastiivgrammatika on keeleteaduse harud, mis tegelevad keelte kõrvutamisega, sisuliselt - võrdlemisega. Sõltumata sellest, kas tegu on mitmeid keeli koondavate tüpoloogiauuringutega (nt Hrakovskij 1985, 1989, 1992, 1998, 2004, Dahl, Koptjevskaja-Tamm 2001, Dahl 2007, 2010, Erelt 1996, 1997, 1999, 2000, 2001) või kontrastiivuuringutega, mis põhinevad enamjaolt kahel keelel, on väga oluline, et eri keelte nähtusi oleks võimalik võrrelda. Eri keelte grammatikakategooriaid saab võrrelda vaid lähtudes nende semantikast ja funktsioonidest. Kategooriate semantika on suuremal või vähemal määral esitatud keelte akadeemilistes grammatikates, mis võimaldab leida vasteid kahe keele kategooriate vahel. Eri keelte võrdlemist hõlbustab oluliselt grammatiliste kategooriate struktuuri analüüs ja sellele järgnev täpsem kirjeldamine.

* Uurimust on rahastanud Eesti Teadusfondi grant nr 9300 “Temporaalsus eesti ja vene keeles". 
Vaatleme artiklis eesti keele grammatikakategooriate põhi- ja sekundaartähendusi eelkõige eesti-vene kontrastiivgrammatika seisukohast, mis aga ei tähenda, et saadud tulemused ei võiks olla kasutatavad ka eesti keele kõrvutamisel mõne teise keelega. Meie hinnangul vajavad selle teema puhul tähelepanu kaks omavahel tihedalt seotud vaatenurka:

1) grammatikakategooriate käsitlus, mis hõlbustaks eesti ja vene keele kõrvutamist kontrastiiv- ja tüpoloogiauuringutes. Näiteks ajakategooria ja selle funktsioneerimine kõnealustes keeltes ei kattu ning vajab detailsemat analüüsi;

2) võrdlemisel tekib paratamatult vajadus ka terminoloogia ühtlustamise järele. Näiteks puudub eesti keele grammatikas vaste venekeelsele oskuskeelendile perenosnoe / metaforičeskoe upotreblenie vremennyh form (ajavormide ülekantud e metafoorkasutus), samas on ühtne terminoloogia kontrastiiv- ja tüpoloogiauuringute jaoks oluline.

\section{Põhitähendus vs. sekundaartähendus}

Igal grammatikakategoorial on olemas põhitähendus (esmane, primaarne tähendus). "Eesti keele grammatikas" on öeldud: "grammatilist tähendust, mida morfoloogiline tunnus (või tunnuse puudumine) väljendab, nimetatakse selle liikme KATEGORIAALSEKS TÄHENDUSEKS. Kategoriaalseid tähendusi võib ühel tunnusel olla ka mitu, kuid enamasti on neist üks primaarne, teised aga sekundaarsed. Paljudel kategooria liikmetel on selgelt eristuv primaarne tähendus" (EKG I: 45). Eri keelte samanimeliste kategooriate esmane tähendus on sageli sarnane (Gak 1988: 8).

Mihhail Šeljakini (2001: 27) sõnul esineb grammatikakategooriate kasutamine ülekantud tähenduses kontekstides, mille semantika on vastuolus sõnavormi esmase tähendusega. Nii näiteks on praesens historicum'i puhul olevikuvorm minevikulises kontekstis ning seetõttu ei väljenda ajavorm enam tegevust olevikus, vaid omandab ülekantud tähenduse ja tähistab olukorda või tegevust minevikus:

(1) Uus tõus Visnapuu loomingus, eriti ta isamaalauludes ja armastuslüürikas algab jälle 1940. aastatel. (EKl)

Sellist nähtust nimetab Aleksandr Bondarko, üks funktsionaalgrammatika loojaid, ajavormide ülekantud ehk metafoorseks kasutuseks (perenosnoe / metaforičeskoe upotreblenie vremenny form), tuues välja ajavormide ülekantud tähenduses kasutamise peamise tunnuse: ajavormi grammatiline tähendus säilib, kuid konteksti vastupidise temporaalse semantikaga kokkupuutumise tulemusel muutub ajavormi tegelik tähendus tavaliselt metafoorseks. Sealjuures nii kontekst kui ka ajavorm viivad tegevuse vastavusse tegeliku ajaga, ainult et üks nendest ajalistest suhetest (see, mida väljendab kontekst) on reaalne, teine aga (mida tähistab verbivorm) on kujundlik, metafoorne. Bondarko rõhutab veel, et sellise vormikasutuse kontekstile on sageli iseloomulik eriline ekspressiivsus ja emotsionaalsus, mistõttu ei sobi metafoorne vormikasutus igasugustesse tekstidesse. Eelkõige esineb ülekantud tähenduses ajavorme ilukirjandustekstides ja kõnekeeles. (Bondarko 1971: 170-174)

Vägagi oluline on eristada grammatilist vormi, selle tähendust keele süsteemis ja kasutusvõimalusi tekstis. Šeljakin (2001: 27) põhjendab seda nii: "Sõna vormi 
kasutamisel ülekantud tähenduses ei muutu selle grammatiline tähendus, see annab kontekstile kujundlik-grammatilise olemuse ja esineb kui sünonüümne vahend.”

Veel üheks sekundaarkasutuse tüübiks, millest räägitakse funktsionaalgrammatikas, on grammatikakategooria neutralisatsioon e üldistusfunktsioon, mis tähendab kategooria liikmete vahelise vastanduse muutumist ebaoluliseks. Näiteks arvukategooria puhul ilmneb see muuhulgas definitsioonide sõnastuses, kus vastandus 'üks vs. rohkem kui üks' pole oluline, kuna öeldu kehtib kogu asjade klassi kohta. Edastatav info ei muutu sellest, kas kasutame ainsust või mitmust (2a), (2b).

(2a) Hunt on kiskja.

(2b) Hundid on kiskjad.

\section{Grammatikakategooriad ja nende tähendused}

Järgnevalt vaadelgem mõningaid eesti keele grammatikakategooriaid ning nende tähendusi lähemalt.

\subsection{Arvukategooria ja pöördekategooria}

Arvukategooria puhul võime väita, et selle eesmärk on väljendada eelkõige esemete, nähtuste, isikute jne arvu: ainsuses - üks, mitmuses - rohkem kui üks. "Tähenduslikult eristavad arvukategooria liikmed üht asja (ainsus) kahest või enamast asjast (mitmus).” (EKG I: 61)

\section{(3a) Tal oli käes üks lilleõis. \\ (3b) Tal oli käes mitu lilleõit.}

Samas on keeltes arvuvorme, mis ei tähenda tegelikult arvu 'üks' või 'mitu'. Tuntud näiteks on plurale tantum ja singulare tantum-sõnad, kuid leidub muidki kasutusi ning kontekste. Kui näiteks tõlkida eestikeelne lause (4) vene keelde, kasutades samu arvuvorme, tekitame arusaamatuse: milleks panna kaks saabast ühte jalga? Ilmselt võib arusaamatusi tekitada ka vene keelest eesti keelde tõlkides (5a), (5b). Vaatamata vormilisele mitmusele (hüperbool!) on venekeelses lauses tõenäoliselt silmas peetud reaalselt ühte teatriskäiku. Eestikeelsest tõlkest jääb mulje, et tegevus on pigem korduv.

(4) Mul on saapad jalas.

(5a) Vy po teatram hodite, a my doma sidim.

(5b) Teie käite mööda teatreid, aga meie istugu kodus.

Kummalgi juhul ei saa tõlkida teise keelde lihtsalt sama grammatilise vormi abil, nagu näitavad mõned tõlketekstid (vt Kupp-Sazonov 2012: 113-128), kuna tegemist pole tavalise, primaartähendusega, vaid ülekantud tähenduse, metafooriga ${ }^{1}$. Niisugune kasutus tekitab raskusi nii tõlkijale kui keeleõppijale, see ei ilmne pelgalt arvuvormide vastandamisel, vaid mingite täiendavate vahendite toel tekstis.

Tegusõnadel esineb arvuvormide ülekantud kasutust teatud pöördevormides. Näiteks on monarhidel ajast aega olnud komme endast rääkides kasutada ainsuse

1 Metafoor on "sõna või väljendi kasutamine sarnasuse alusel uudses, ülekantud tähenduses; (laiemalt:) igasugune 
1. pöörde asemel mitmuse 1. pööret (6). Mati Erelt (1990: 37) nimetab seda kasutusviisi klassikaliseks majesteedimitmuseks.

(6) Meie, Erik Neljateistkümnes, Jumala armust rootslaste, gootide ja vendide .. kuningas .. (EK)

Vene teaduskeeles on olnud pikka aega stiilivõtteks mitmuse 1. pöörde kasutamine (ka ühe autori puhul) selleks, et olla tagasihoidlikum ja tunnustada oma eelkäijate panust teadusesse. Ka eesti keeles kasutatakse seda võtet mõnikord, kuigi "keelekorraldajad taunivad autorimitmuse kasutamist kui ebasobivat enesekergitamise viisi. Mitmuse 1. pööret peetakse loomulikuks vaid siis, kui ta esineb otsetähenduses, st osutab ühteaegu nii autorile kui ka kuulajale." (Erelt 1990: 37) Seega on eesti teaduskeele seisukohast eelistatum umbisikulise tegumoe kasutamine või viitamine töö autorile ainsuse 3. pöördes ning meie-vormi tuleks kasutada vaid mitme autoriga kirjutise puhul.

(7a) V pervoj glave rassmotrim...

(7b) Esimeses peatükis vaadeldakse...

"Grammatiline isiku- ja arvukategooria realiseerub morfoloogilise pöördekategooriana, millel on kolm ainsuslikku ja kolm mitmuslikku liiget.” (EKG II: 27). Pöördekategooria võimaldab nii eesti, kui vene keeles sekundaarkasutusi ning paljudel juhtudel need ka kattuvad. Näiteks võib ema oma lapsest rääkides kasutada ainsuse 3. pöörde asemel (tema) hoopis mitmuse 1. pööret (meie):

(8) Meil tulevad praegu hambad ja seepärast tahame kõike suhu toppida. Arst võib meilt küsida mitmuse 1. pöördes:

(9) Ja kuidas me ennast täna tunneme?

\subsection{Ajakategooria}

Ajakategoorias on keskne vastandus olevik vs. minevik, samas võib leida kontekste, kus on võimalik olevikuvorm vahetada minevikuvormi vastu ilma mõtte sisu muutmata.

(10a) Suur tükk ajab suu lõhki.

(10b) Suur tükk ajas suu lõhki: Levada Olümpia vastas asuvad kinnistud sundmüügis. (ST)

Kui arvukategooria puhul võib rääkida lihtsalt eelistusest, näiteks lause (2a) puhul valib kõneleja tõenäoliselt pigem ainsuse vormi, siis ajavormide neutralisatsiooni puhul on olukord pisut keerulisem. Näiteks olevikuvormi asendamine minevikuvormiga toob kaasa lisatähenduse - viite mingile konkreetsele juhtumile, kus tuntud vanasõna kinnitust leidis. Sellest hoolimata võib väita, et väljaöeldud mõte sellest ei muutu, st fakt, et suur tükk ajab suu lõhki, kehtis minevikus mingis konkreetses olukorras ja kehtib edasi olevikus. Ka neutralisatsioon vajaks kahtlemata süvendatud uurimist, kuid siinse artikli raames piirdume vaid grammatikakategooriate metafoorkasutuste analüüsimisega. 
Samanimeliste grammatikakategooriate puhul kahes keeles ilmneb iga keele eripära just sekundaartähendustes, samas primaartähendused on sageli sarnased. Seetõttu esineb keeleõppijail emakeele häiriv mõju õpitavale keelele e interferents just grammatikakategooria liikme (resp. grammatilise tähenduse) sekundaarkasutuses. Siiski peab ütlema, et arvu- ja pöördekategooria kasutuses ei ole vaadeldavates keeltes väga suuri erinevusi; olulisemad on need tegusõna ajakategooria liikmetel.

Hoolimata eesti keele grammatika põhjalikust uuritusest ei ole vormide sekundaarsed kasutusviisid veel piisavalt tähelepanu pälvinud. Selle tõestuseks on kasvõi asjaolu, et siiani ei ole erialakirjanduses kujunenud välja ühte konkreetset oskuskeelendit vaadeldava nähtuse tähistamiseks. Olgu öeldud, et terminit sekundaarne kasutus kohtab "Eesti keele grammatika I. Morfoloogia. Sõnamoodustus" tekstis vaid ühe korra: "Imperfekti sekundaarseid kasutusi on a) nn meenutusminevik" (EKG I: 77). Samas kalduvad käesoleva artikli autorid arvama, et täpsem oskuskeelend üldnimetusena niisuguste kasutusjuhtude jaoks oleks metafoorkasutus (kuivõrd selle tulemusena tekib vormil metafoorne e kujundlik tähendus), mille alaliikideks oleks ka meenutusminevik, ajalooline olevik jt.

Üks sagedasemaid metafoorkasutusi ongi olevikuvormi paigutamine minevikulisse konteksti, mistõttu preesensivorm omandab metafoorse tähenduse (1). Kui üritada viia metafoori tähendust pelgalt sõna tasemelt ka teistele keeletasanditele, võib öelda, et praesens historicum'i korral kasutatakse olevikuvormi mineviku kontekstis kujundlikult, sest selle loomulik (primaarne, esmane) tähendus (väljendada tegevust mitteminevikulisel ajahetkel) muutub vastupidiseks.

Eesti keeles on kindlas kõneviisis neli ajavormi: olevik, lihtminevik, täisminevik ja enneminevik. Tulevikus asetleidva tegevuse väljendamiseks kasutatakse olevikuvormi koos tulevikule viitavate ajamääruste või kontekstiga. Leidub ka mõningaid verbe, mis ei märgi oleviku tegevust, vaid sisaldavad viiteid tulevikule oma leksikaaltähenduses (hakkama, algama, saama, tulema jms). Teiste tegusõnade puhul on olevikuvormil vaja konteksti tuge, et väljendada tulevikku. Eraldi võib arutleda selle üle, kas olevikuvormi kasutamine tulevikulise tegevuse või olukorra väljendamiseks on samuti selle ajavormi ülekantud ehk metafoorkasutus või mitte, kuna futuurumi tähendus tekib konteksti toel.

Igal ajavormil on oma tähendus, keeleõppijale antakse samuti küllaltki konkreetsed juhised, millal millist ajavormi kasutada. Seejuures aga peetakse enamjaolt silmas vaid aegade esmaseid tähendusi ja neidki mitte kõiki. Nagu väidavad Raili Pool ja Helle Metslang (ilmumas), ei käsitleta eesti keele õpikutes tuleviku väljendamist (v.a Roman Kallase 2011. a õpik). Hoolimata eesti keele ajakategooria põhjalikust uurimisest (nt Metslang 1994, 1997), pole nn sekundaarsed kasutused piisavalt tähelepanu pälvinud.

Siiski võib erinevatest eesti keele grammatika käsitlustest leida vähemalt viis erinevat sekundaartähendust (kaks oleviku ja kolm minevikuvormidel), mis siiani ei ole leidnud kohta ühtses ajavormide süsteemis.

Olevikuvormil eristatakse kahte peamist sekundaartähendust.

1) Praesens historicum ehk ajalooline olevik: olevikus esinev öeldisverb "võib väljendada ka m i n evi ku s a s e t l e i d n u d [---] tegevust või olemist" (Mihkla, Valmis 1979: 34), st olevikuvorm esineb minevikule viitavas kontekstis. 
(11) 1941. a mängib "Vanemuine" edutult Mart Raua draamat "Mõõk väravas”, mille tegelasteks on kommunistidest poliitvangid. (EKl)

Keeletüpoloogia ja kontrastiivgrammatika, samuti keeleõppe ja tõlke seisukohast mängib see konkreetne metafoorkasutus eriti olulist rolli. Nimelt on selline olevikuvormi kasutusviis väga populaarne vene ilukirjanduses ja kõnekeeles, seetõttu on oluline välja selgitada, kas praesens historicum on mõlemas keeles kasutatav samadel tingimustel. Juba Valter Tauli on raamatus "Eesti keele grammatika II. Lauseõpetus" märkinud, et lihtmineviku vormi asemel ei saa olla olevikuvorm siis, kui verbi laiendab minevikku märkiv väljend nagu eile, möödunud nädalal, kahe aasta eest (Tauli 1980: 33). Siiani leitud näited nagu (12b) näivad kinnitavat seda väidet selgelt piiritletud ajalõiku tähistava ajamääruse kasutamisel (nt möödunud nädalal tähendab jooksva nädala esmaspäevale eelnevat seitset päeva).

(12a) Včera v polnoč’ prohožu čerez stolovoju, a tam sveča gorit. (AČv)

(12b) Eile läksin südaöösel läbi söögitoa, seal põles küünal. (AČe)

(12c) *Eile lähen südaöösel läbi söögitoa, seal põleb küünal.

Samas on eesti keeleuurijate väitel see suulises kõnes võimalik sõnajärje muutmisel (Lähen eile südaööl...). ${ }^{2}$

2) Praesens referens ehk refereeriv olevik - seda "kasutatakse peamiselt kirjandus- ja kunstiteoste sisu ja vormi kirjeldamisel ning seletamisel” (Mihkla, Valmis 1979: 35).

(13a) Tsvetajeva ei mängi lugejaga võrdsust, ta võrdsustab ennast lugejaga leksikaalselt, loogiliselt.

(13b) Cvetaeva ne igraet s čitatelem $\mathrm{v}$ ravenstvo: ona sebja $\mathrm{k}$ nemu priravnivaet leksičeski, logičeski. (JBr)

Vene grammatikates nimetatakse sellist kasutust eksponeerivaks olevikuks (nastojaščee èkspozicionnoe) (Petruhina 2009: 135). Peale selle on Bondarko toonud välja veel nastojaščee èmocional'noj aktualizacii (emotsionaalselt aktualiseeritud olevik), millel põhimõtteliselt on ajaloolise minevikuga sama funktsioon, kuid seda iseloomustab veelgi suurem emotsionaalsus ja ekspressiivsus.

(14a) My, sidja v Uzle, sovsem zaplesneveli, a tut vdrug javljaetsja soveršenno svežij čelovek, s gromadnoj èrudiciej... (DMSv)

(14b) Kükitades siin Uzelis olime juba päris hallitanud, aga äkki ilmub meie hulka täiesti värske inimene, tohutu eruditsiooniga... (DMSe)

Šeljakin (2001: 104) kirjeldab ajaloolise oleviku ja emotsionaalselt aktualiseeritud oleviku erinevust: "Ajavormi kasutusviisi osas ei erine emotsionaalselt aktualiseeritud olevik mitte millegi poolest ajaloolisest olevikust, kuid sel on stilistiline eripära: see ei ole näitlik, vaid väljendab kõneleja subjektiivset hinnangulist suhtumist erinevatesse mineviku faktidesse."

Praesens historicum'i on kirjeldatud ka näiteks saksa, hispaania jt keeltes. 
Minevikuvormil võib välja tuua järgmised kasutusviisid.

1) Meenutusminevik: "tuletades meelde minevikus teadasaadut kasutatakse minevikku vaatamata sellele, et öeldu võib sisuliselt kehtida olevikuski” (EKG I: 77).

(15a) Kas Teie nimi oli Tamm?

(15b) *Vaša familija byla Tamm?

Vene keele minevikuvormil kirjakeeles seda sekundaartähendust ei ole, lauset (15b) saab mõista vaid ühtmoodi: kõnetatu perekonnanimi on küsimise hetkeks muutunud. Kui inimene pole sekundaartähendusest teadlik, siis võib selline küsimus eesti keeles põhjustada mitte-emakeelekõneleja jaoks segadust: küsija soovib kontrollida oma teadmist, vastajale aga võib jääda mulje, et küsimus puudutab tema eelmist perekonnanime.

Esmased analüüsitulemused näitavad, et tõenäoliselt võimaldavad sellist kasutusviisi ka teised tegusõnad. Järgnev näide (16) on pärit ühest tavavestlusest, osapool A räägib eesti keelt emakeelena, teine osaleja B on kakskeelne (eesti ja vene).

(16) A: Kas Siim elab nüüd Prantsusmaal?

B: Jah, juba aasta.

A: Oot, mida ta seal õppis, õigusteadust?

B: Ta õpib praegu ka - jah, õigusteadust.

Olukord on sarnane näitelausetega (15a), (15b). Vestluses osaleja A soovib vaid Siimu puudutavat informatsiooni kontrollida, samal ajal kui vestluspartner B mõistab tema küsimust hoopis teisiti ning seetõttu parandab A-d.

2) Tuleviku minevik: "täismineviku vormi kasutatakse ka siis, kui kõnehetkele järgnevat tegevust vaadeldakse mingi veel hilisema vaatlushetke seisukohalt (tuleviku minevikus)" (EKK: 279), st minevikuvormi kasutatakse tuleviku kontekstis.

(17a) Loodame, et pühapäeva õhtuks oled sa selle töö lõpetanud.

(17b) Budem nadejat'sja, čto k večeru ty zakončiš’ ètu rabotu.

Vene keeles on näites (17b) tegu perfektiivse aspekti tulevikuvormiga selle primaartähenduses.

Kõrvutagem nüüd eesti keele võimalusi minevikuvormi kasutamisega ülekantud tähenduses vene keeles.

3) Kujutletav tulevik (buduščee voobražaemoe Bondarko järgi): perfektiivse minevikuvormi kasutamine tuleviku kontekstis (18a). Eestikeelses tõlkes ei ole vasteks minevikuvorm, vaid tulevikku väljendav olevikuvorm (18b). Siiski võiks ka eestikeelses lauses olla verb liht- või täisminevikus (18c).

(18a) Nu, položim, ja sdelaju usilie, sdelaju èto. Ili ja poluču oskorbitel'nyj otvet, ili soglasie. Horošo, polučila soglasie... [---] Ja poluču soglasie, a sy... syn? (LTv)

(18b) Noh, oletame, et ma sunnin ennast seda tegema, ma teen seda. Ma saan kas eitava või jaatava vastuse. Hästi, ma saan nõusoleku... [---] Ma saan nõusoleku, aga poeg... poeg? (LTe) 
(18c) Ma saan kas eitava või jaatava vastuse. Hästi, ma sain / olen saanud nõusoleku...

Analoogiline metafoorkasutus on võimalik ka vene tingimuskõrvallausega lausetes, kuid see pole stiililt neutraalne, vaid ekspressiivne (Bondarko 1971: 132).

(19a) Esli zavtra ne budet doždja - urožaj pogib. (ATv)

(19b) Kui homme vihma ei tule, hävib vili / on vili hävinud. (ATe)

Nii eesti kui vene kõnekeeles esineb ka mõningate verbide ekspressiivset lihtminevikuvormi kasutust, nt kavatsusena: Noh, ma sïs läksin! Nu, ja pošël!

Kuna artikli maht ei võimalda kõikide metafoorkasutuste käsitlemist, siis piirdume eelpool loetletuga. Käsitletud metafoorkasutused võtab kokku tabel 1, lisatud on vastavate näidete numbrid.

Tabel 1. Ajavormide sekundaartähendused eesti ja vene keeles

\begin{tabular}{|c|c|c|}
\hline Sekundaartähendus & Eesti keel & Vene keel \\
\hline $\begin{array}{l}\text { Praesens historicum } \\
\text { (olevikuvorm mineviku } \\
\text { kontekstis) }\end{array}$ & $\begin{array}{l}+ \\
(11)\end{array}$ & $\begin{array}{l}+ \\
\text { (sh emotsionaalselt } \\
\text { aktualiseeritud olevik) } \\
(12 a)\end{array}$ \\
\hline $\begin{array}{l}\text { Praesens referens / eksponeeriv } \\
\text { olevik (olevikuvorm mineviku } \\
\text { kontekstis) }\end{array}$ & $\begin{array}{l}+ \\
(13 a)\end{array}$ & $\begin{array}{l}+ \\
(13 b)\end{array}$ \\
\hline Meenutusminevik & $\begin{array}{l}+ \\
\text { (lihtminevikuvorm oleviku } \\
\text { kontekstis) } \\
(15 a)\end{array}$ & - \\
\hline Tuleviku minevik & $\begin{array}{l}+ \\
\text { (täisminevikuvorm tuleviku } \\
\text { kontekstis) } \\
\text { (17a) }\end{array}$ & - \\
\hline Kujutletav tulevik & $\begin{array}{l}+ \\
\text { (täis- või lihtminevikuvorm } \\
\text { tuleviku kontekstis) } \\
(18 c)\end{array}$ & $\begin{array}{l}+ \\
\text { (perfektiivse aspekti mineviku- } \\
\text { vorm tuleviku kontekstis) } \\
\text { (18a) }\end{array}$ \\
\hline
\end{tabular}

\section{Terminoloogia}

Eraldi tähelepanu väärib ka see, kuidas kirjeldatud keelenähtusi eesti keeles nimetada, nii et terminite süsteem oleks piisav tüpoloogiliste ja kontrastiivsete uuringute jaoks ning ühtne muude keelte terminitega. Loomulikult tuleb enne iga termini loomist ja kasutuselevõttu küsida, kas keeles on üldse vajadust uue oskussõna järele.

Olukord oleks erinev, kui eesti keeles ajavormide kasutamist ülekantud tähenduses üldse ei esineks, sellisel juhul puuduks ka otsene vajadus oma oskuskeelendi 
järele. Nii kasutavad Triin Lõbus ja Silvi Tenjes (2010: 157) terminit narratïune imperfekt ning lisavad, et "erinevalt eesti grammatikatraditsioonist, kus terminit imperfekt kasutatakse üldise lihtmineviku tähenduses, mõistame käesolevas artiklis selle all hispaania keele imperfektiivse aspektitähendusega minevikuvormi [---]. Narratiivseks imperfektiks nimetatakse romaani keeltes narratiivses diskursuses esinevat eripärast aspektikasutust, mille puhul imperfektiivset verbivormi kasutatakse selliste sündmuste kujutamiseks, mille ajalis-aspektiline iseloom eeldaks perfektiivset aspekti.” Analüüsitav nähtus esineb romaani keeltes, seega pole eestikeelse termini olemasolu ilmtingimata vajalik, kontrastiivuuringutes on võimalik kasutada hispaania terminile vastavat võõrsõna. Ajavormide kasutamine ülekantud tähenduses on aga igati omane ka eesti keelele, seega on vajadus omakeelse termini järele tunduvalt rohkem põhjendatud.

Tegelikult vajaksime koguni kahte oskuskeelendit: üks tähistaks ajavormi kasutamist selle esmases (primaarses, põhilises, prototüüpses) tähenduses (nt kui olevikuvorm märgib sündmuste toimumist kõnehetke suhtes mitteminevikulisel ajahetkel) ja teine sekundaartähendust (nt praesens historicum).

Vaadelgem, millised nimetused on sekundaarkasutuste kohta kasutusel eesti keelt käsitlevas grammatikakirjanduses (teosed on esitatud kronoloogilises järjestuses).

Venekeelne eesti ja vene keele kõrvutav grammatika (1962): üldtermin puudub, juttu on praesens historicum'i tähendusest - olevikuvormi kasutamisest "v značenii nastojaščego istoričeskogo" (Päll jt 1962: 155). Minevikuvormide võimalikke metafoorkasutusi ei ole käsitletud.

"Eesti keele süntaksi küsimusi" (1963): Boriss Serebrennikov (1963: 444-449) kirjutab olevikuvormide tüüpidest, mille hulgas on eraldi välja toodud praesens historicum, praesens tabulare jms. Lisaks eristab ta veel variante: osnovnoe značenie (põhitähendus) ja derivatnoe značenie (tuletatud tähendus), pidades viimase all silmas näiteks olevikuvormiga mingi objekti alalise omaduse tähistamist.

"Eesti keele lauseõpetuse põhijooned I" (1974): kasutatakse sõna põhitähendus: "Peale oma põhitähenduse võib olevikus esinev öeldisverb väljendada olendile, esemele või nähtusele püsivalt iseloomulikku tegevust, seisundit või tunnust" (Mihkla jt 1974: 91). Kuigi autorid ei tähista olevikuvormi mittepõhilisi kasutusviise ühegi oskussõnaga, võib eeldada, et terminile põhitähendus võiks vastandada nt sekundaartähenduse, kõrvaltähenduse jms.

"Eesti keele süntaks kõrgkoolidele" (1979): sarnaselt eelmisele käsitlusele on ka siin kasutusel põhitähendus: "Peale põhitähenduse võib olevikus öeldisverb väljendada ka minevikus asetleidnud või tulevikus toimuvat tegevust või olemist" (Mihkla, Valmis 1979: 34).

Teistest erinev ja teatud määral keerulisem on olukord Tauli grammatikaraamatus "Eesti grammatika II. Lauseõpetus" (1980): autor kasutab läbivalt, ka muudes kontekstides kui verbist rääkides, sõna esinemine. Seega ei saa väita, et tegu oleks terminiga, pigem tähendab see Tauli jaoks sama mis kasutamine, tähistades lihtsalt erinevaid kasutusnäiteid: "Esinemine: (1) kui tegevusaega ei väljendata või tegevus toimub alati [---]" (Tauli 1980: 32).

"Eesti keele grammatika I. Morfoloogia. Sõnamoodustus" (1995) annab eelmainitud sekundaarse kasutuse (EKG I: 77). Tähelepanu väärib asjaolu, et kõnealust terminit on kasutatud vaid üks kord (imperfekti puhul), kuigi ka olevikuvormil on eesti keeles oma sekundaartähendused täiesti olemas. 
Uuematest käsitlustest tuleks nimetada veel näiteks Pille Esloni, Katre Õimu, Annekatrin Kaivapalu, Reili Arguse ja Erika Matsaki ühisartiklit "Kuidas uurida esimese ja teise keele omandamist?”, kus autorid viitavad kõnealusele nähtusele järgneval viisil:

Sõnade ja väljendite mõistestamisel tugineb inimene suuresti oma kogemusele ning sellest tulenevalt metafoorsele, metonüümsele vm laadi analoogiapõhisele mõtlemisviisile, mis motiveerib meie keelekasutust oluliselt suuremal määral, kui arvatud. See ilmneb sõnade, vormide ja süntaksistruktuuride kasutamises ülekantud tähenduses (fraseologismid, registrierinevustega seotud vormivariatiivsus jne) või neile mitteomases funktsioonis [siinne esiletõst] (nt praesens historicum või verbi 2. pöörde üldistatud kasutamine kelle tahes suhtes, kes situatsiooni kogevad: See kordumatu igaviku tunne, kui istud nïsugustel sügisõhtutel kodusoojas ja kuulad raugeva tormi müha!). (Eslon jt 2010: 18)

Siinkohal tahaksime juhtida tähelepanu väljendile mitteomases funktsioonis, sest seda pole kõnealuses artiklis pikemalt lahti seletatud. Kuna autorid lisavad, et "Neid nähtusi ei saa pidada anomaaliaks: tegu on keelele omase iseorganiseerumisvõime ilmnemisega, tänu millele on omavahel tasakaalus keele säilimine ja pidev tsükliline uuenemine" (Eslon jt 2010: 18), siis tekib küsimus: kui keel võimaldab sellist kasutusviisi, kas seda saab nimetada mitteomaseks või on tegu pigem lihtsalt tavakasutusest erineva nähtusega?

Vene keele grammatikas ongi kasutusel keelend perenosnoe / metaforičeskoe upotreblenie vremennyh form ehk 'ajavormide ülekantud / metafoorne kasutus' (vt lähemalt Bondarko 1971: 129-237, Bondarko 2002: 191, Šeljakin 2001: 98-111, Knjazev 2007: 79). Eelmainitud artiklis kasutavad autorid sõnaühendit ülekantud tähenduses kasutamine fraseologismide ja vormivariatiivsuse kohta. Ühes varasemas Esloni artiklis (2006: 365) esineb termin ülekantud tähenduses kasutamine seoses aspektisituatsioonidega vene keeles.

Vaadelgem lähemalt ka ingliskeelsetes käsitlustes leiduvaid nimetusi.

Östen Dahl vastandab omavahel kahte nähtust: prototypical use (prototüüpne, põhiline kasutamine) ja secondary use (sekundaarne kasutamine): "The prototypical uses of FUT that we have cited have clear future time reference. It is well known that many categories called 'Future' can also be used for 'predictions' or 'inferences' about non-future states of affair. It is reasonable, however, to regard this as a secondary use of FUT categories, which preserves one element of the prototypical uses, viz. that of prediction (in the wide sense of that word) although leaving out the others." (Dahl 1985: 108) Niisiis on tuleviku prototüüpsetel kasutusviisidel selge viide tulevikule, aga futuurumi sekundaarne kasutamine tähendab, et säilib üks prototüüpse kasutuse elementidest, ning teised jäävad välja.

Bernard Comrie (1995: 43) eelistab sõnaühendit normal usage: "The usages noted so far in this section have typically shifted the tense (e.g. present for past), and either shifted aspect in accordance with normal usage in the present, or retained aspect in accordance with the distinction between description and narration." Comriel puudub sõna tähistamaks ajaloolise oleviku laadset ajavormi kasutamist, ta viitab vaid sellele, et tegu on teatud nihkega tavalisest kasutamisest. 
Renaat Declerck (2006: 27) kasutab kahte väljendit: special uses of tenses (ajavormide erikasutused) ja metaphorical uses (metafoorsed kasutused): "Some tenses have one or more metaphorical uses: they are used to represent a particular time as if it were another time. The present tense, for example, can be used to refer not only to the present, but also to the past and to the future. For example, in narration we often find a switch from the past tense to the 'historic present'." Seega väidab Declerck, et mõnedel ajavormidel on üks või mitu metafoorset kasutusvõimalust, mille käigus need peavad väljendama mingit aega nii, nagu oleks tegu hoopis teise ajaga, ehk siis olevikuvormiga saab väljendada tegevust minevikus või tulevikus.

Tähelepanuväärne on see, et näiteks James Forsyth ei pea praesens historicum’i sugugi olevikuvormi sekundaarseks ega ka mitte metafoorseks kasutamiseks, vaid liigitab ajaloolise oleviku preesensivormi põhitähenduste (basic meanings) hulka: "The basic meanings are: (a) the 'real' or actual present [---] (c) the historic present, used in narrating past events" (Forsyth 1970: 147). Kõike, mis ei mahu põhitähenduste alla, nimetab ta eccentric usage (iseäralikud kasutusviisid): “Eccentric' usages of present-future forms in the 'real' mode are few. As in many languages, including English, the (imperfective) present tense can be used to refer to a future action [---]" (Forsyth 1970: 149). Forsythi hinnangul on vene olevikuvormi kasutamine tuleviku tähenduses just selline iseäralik kasutusvariant.

Suzanne Fleischman, kes on põhjalikult uurinud ajavormide kasutamist narratiivis, eelistab rääkida sellistest nähtustest nagu basic tense function (ajavormi põhifunktsioon) ja not basic tense function: "What I propose to demonstrate here is that the function of tense forms IN NARRATIVE is frequently not the basic tense function of locating events relative to the moment of speech (or an alternative reference point)" (Fleischman 1985: 852). Jutustavat olevikku nimetab ta oleviku variandiks (variety): "the term narrative present $(=\mathrm{NP}$ ) will be used to designate that variety of present" (Fleischman 1985: 867). Sünonüümiks 'põhifunktsioonile' on tema töödes veel 'põhitähendus' (basic meaning): "grammatical meanings, including the so-called 'basic' meanings or functions of tense and aspect” (Fleischman 1991: 77).

Loomulikult ei ole siin loetletud võimalike terminite nimekiri ammendav, kindlasti võib grammatikakäsitlustest leida veel teisigi variante. Kuid kuna artikli eesmärk ei ole esitada lõplikku loetelu kõikidest võimalikest oskuskeelenditest, siis piirdume eeltooduga. Juba see küllaltki lai terminite valik kinnitab veelkord veendumust, et vajadus ühe konkreetse termini järele on eesti keele grammatika kirjeldamisel olemas.

\section{Kokkuvõte}

Kuigi ajavormide kasutamine (sh ülekantud tähenduses) eesti ja vene keeles sajaprotsendiliselt ei kattu, näib siiski, et ka eesti keeles on rohkem aegade metafoorkasutusi, kui võiks esmapilgul arvata. Grammatiline metafoor on süsteemne nähtus, mis tugineb grammatilise vormi semantilisel potentsiaalil ning vajaks eesti grammatikas veel uurimist. Meie arvates võimaldaks ja hõlbustaks grammatiliste tähenduste struktuuri põhjalikum vaatlus kahe keele kõrvutamist ning tüpoloogiauuringuid. Ühtlasi võimaldab ülekantud kasutuste tundmine ka sellist keele õpetamist, kus vaadeldakse esmalt põhitähendusi ning seejärel keeleõppe 
kõrgtasemel ja tõlkeõpetuses käsitletakse juba ka grammatikakategooriate metafoorseid funktsioone (vt näited 15a, 15b ja 16).

Terminoloogia seisukohast on meil vaja leida vastus kahele põhiküsimusele.

1) Kas eesti keele grammatikas on vaja kõnealuse nähtuse tähistamiseks terminit? Vastamisel tasuks lähtuda Tiiu Erelti (2007: 69) püstitatud küsimusest: "kas mõiste on erialal nii oluline, käibiv või iseseisev, et üldse vajab nimetamist, või piisab kirjeldusest?” Meie hinnagul on tegu piisavalt olulise ja iseseisva nähtusega. Selle argumendi kasuks räägib juba seegi, et oleme siin tutvustanud vähemalt viit ajavormide kasutamisvõimalust ülekantud tähenduses (kaks oleviku- ja kolm minevikuvormide puhul), seega ei saa väita, et tegu oleks marginaalse nähtusega, mille tähistamiseks me terminit ei vaja.

2) Kui leiame, et vajadus termini järele selle grammatilise nähtuse tähistamise jaoks on olemas, samas aga kinnistunud oskuskeelend eesti keele grammatikas puudub, siis on vaja jõuda selgusele, kas peaksime välja mõtlema täiesti uue termini, võtma kasutusele mõne juba kirjanduses esinenud variandi või võime laenata selle ka mõne teise keele grammatikast.

Põhimõtteliselt võiks kasutada "Eesti keele grammatikas" esinevat sõna sekundaarkasutus, kuid võib tekkida küsimus, kas see termin annaks täies mahus edasi seda, mis tegelikult ajavormi ja selle tähendusega juhtub, kui näiteks olevikuvorm satub mineviku konteksti vms. Kui kasutada olevikku minevikulises kontekstis, siis võib öelda, et preesensivorm omandab metafoorse tähenduse. Metafoor võib esineda mitte pelgalt sõna tasemel, vaid ka teistel keele tasanditel, nimelt grammatikas (Metslang 2001: 222-231), nt kui ajavormi kasutatakse talle mitteomases kontekstis.

Veel ühe argumendina selle poolt, et metafoorkasutus oleks veidi täpsem termin kõnealuse nähtuse tähistamiseks, võib võrrelda muid olukordi, kus räägitakse samuti sekundaarkasutustest. Näiteks võib väita, et küsilause sekundaarkasutuseks on retooriline küsilause (Kes sïs tänapäeval enam postkaarte saadab?), millele selle esitaja ei ootagi vastust, kuid ometi ei kaota retooriline küsimus täies ulatuses küsimuse esmast funktsiooni ja tähendust, sest soovi korral võib ka retoorilisele küsimusele siiski vastata. Olevikuvorm minevikulises kontekstis või minevikuvorm oleviku kontekstis kaotab aga täielikult oma nn esmase funktsiooni ja omandab sõltuvalt ümbritsevast kontekstist sootuks vastupidise tähenduse.

Kahtlemata üheks võimaluseks, mida tasub kaaluda, on ka sobiva termini n-ö laenamine. Heaks näiteks on perfektitüübid, millele juhtis tähelepanu Comrie (1976: 56-61) ning mille Helle Metslang ja Mati Erelt edukalt ka eesti keele grammatikas kasutusele võtsid (Metslang 1997: 102-106, Erelt, Metslang 1998: 665-667). Artikli autoritele tundub, et kõige paremini annaks ajaloolise oleviku, meenutusmineviku jms olemust edasi termin, mis sisaldaks viidet kasutusele ülekantud tähenduses, seejuures ülekande tüübi täpsem eritlus oleks juba edasise uurimise ülesanne. Seetõttu tuleks meie analüüsist lähtudes kõne alla venekeelsele terminile analoogiline oskuskeelend metafoorkasutus, mis võimaldaks mõista ajavormide ülekantud tähenduses kasutamise olemust. 


\section{Materjali allikad}

AČe = Tšehhov, Anton 2006. Näidendid. Tõlk. Ernst Raudsepp, Otto Samma. Tallinn: Avita. AČv = Tšehhov, Anton 1982. P’jesy. Moskva.

ATe $=$ Tolstoi, Aleksei 1974. Nikita lapsepõlv. Tõlk. Jüri Piik. Tallinn: Eesti Raamat.

ATv $=$ Tolstoj, Aleksej 1983. Detstvo Nikity. Minsk: Junactva.

DMSe = Mamin-Sibirjak, Dmitri 1952. Privalovite miljonid. Tõlk. Nelly Toiger. Tallinn: Eesti Riiklik Kirjastus.

DMSv = Mamin-Sibirjak, Dmitrij 1958. Privalovskie milliony. Orel.

EK = Küng, Enn. 2011. "Paludes kristlikku päästmist ja kaitset": Eestimaa seisuste alistumine Rootsi võimule 1561. aasta suvel. - Tuna, 3, 88-98.

EKl = Annus, Epp; Epner, Luule; Järv, Ants; Olesk, Sirje; Süvalep, Ele; Velsker Mart 2001. Eesti kirjanduslugu. Tallinn: Koolibri.

$\mathrm{JBr}=$ Brodski, Jossif 1992. Stihotvorenija, èsse, p’jesy. Minsk: Èridan.

$\mathrm{LTe}=$ Tolstoi, Lev 1978. Anna Karenina. Tõlk. Selma Holberg. Tallinn: Eesti Raamat.

LTv $=$ Tolstoj, Lev 1976. Anna Karenina. Moskva: Hudožestvennaja literatura.

ST = Suur tükk ajas suu lõhki: Levada Olümpia vastas asuvad kinnistud sundmüügis. Ärileht, 7.11.2012. http://arileht.delfi.ee/news/uudised/suur-tukk-ajas-suu-lohkilevada-olumpia-vastas-asuvad-kinnistud-sundmuugis.d?id=65226732 (4.10.2013).

\section{Viidatud kirjandus}

Bondarko, Aleksandr 1971. Vid i vremja russkogo glagola. [Aspect and Tense of the Russian Verb.] Moskva.

Bondarko, Aleksandr 2002. Teorija značenija v sisteme funkcional'noj grammatiki. [The Theory of Meaning in the System of Functional Grammar.] Moskva.

Comrie, Bernard 1976. Aspect. An Introduction to the Study of Verbal Aspect and Related Problems. Cambridge: Cambridge University Press.

Comrie, Bernard 1995. Aspect. An Introduction to the Study of Verbal Aspect and Related Problems. Cambridge: Cambridge University Press.

Dahl, Östen 1985. Tense and Aspect Systems. Blackwell Publishers.

Dahl, Östen 2007. From Questionnaires to Parallel Corpora in Typology. - Sprachtypologie und Universalienforschung, 60, 172-181.

Dahl, Östen 2010. Typology of negation. - Laurence R. Horn (Ed.). The Expression of Negation. Berlin: De Gruyter Mouton, 9-38.

Östen Dahl; Koptjevskaja-Tamm, Maria (Eds.) 2001. Circum-Baltic Languages. Vol. 1: Past and Present. Studies in Language Companion Series 54. Amsterdam: Benjamins.

Declerck, Renaat 2006. The Grammar of the English Verb Phrase. Vol. 1: The Grammar of the English Tense System. Berlin, New York: Mouton de Gruyter.

EKG I = Erelt, Mati; Kasik, Reet; Metslang, Helle; Rajandi, Henno; Ross, Kristiina; Saari, Henn; Tael, Kaja; Vare, Silvi 1995. Eesti keele grammatika I. Morfoloogia. Sõnamoodustus. [The Grammar of the Estonian Language I: Morphology. Word-formation.] Eesti Teaduste Akadeemia Eesti Keele Instituut. Tallinn.

EKG II = Erelt, Mati; Kasik, Reet; Metslang, Helle; Rajandi, Henno; Ross, Kristiina; Saari, Henn; Tael, Kaja; Vare, Silvi 1993. Eesti keele grammatika II. Süntaks. [The Grammar of the Estonian Language II: Syntax.] Eesti Teaduste Akadeemia Keele ja Kirjanduse Instituut. Tallinn.

EKK = Erelt, Mati; Erelt, Tiiu; Ross, Kristiina 2007. Eesti keele käsiraamat. [The Handbook of Estonian.] Tallinn: Eesti Keele Sihtasutus.

EKSS = Langemets, Margit; Tiits, Mai; Valdre, Tiia; Veskis, Leidi; Viks, Ülle; Voll, Piret (Toim.) 2009. Eesti keele seletav sõnaraamat 1-6. [The Explanatory Dictionary of Estonian.] Tallinn: Eesti Keele Sihtasutus. 
Erelt, Mati 1990. Kõneleja ja kuulaja kaudse väljendamise võimalusi eesti keeles. [The possibilities of expressing the speaker and the listener in an indirect way in Estonian.] Keel ja Kirjandus, 1, 35-39.

Erelt, Mati (Ed.) 1996. Estonian: typological studies I. Publications of the Department of Estonian of the University of Tartu 4. Tartu: Tartu University Press.

Erelt, Mati (Ed.) 1997. Estonian: typological studies II. Publications of the Department of Estonian of the University of Tartu 8. Tartu: Tartu University Press.

Erelt, Mati (Ed.) 1999. Estonian: typological studies III. Publications of the Department of Estonian of the University of Tartu 11. Tartu: Tartu University Press.

Erelt, Mati (Ed.) 200o. Estonian: typological studies IV. Publications of the Department of Estonian of the University of Tartu 14. Tartu: Tartu University Press.

Erelt, Mati (Ed.) 2001. Estonian: typological studies I. Publications of the Department of Estonian of the University of Tartu 18. Tartu: Tartu University Press.

Erelt, Mati; Metslang, Helle 1998. Oma või võõras? [Our own or foreign?] - Keel ja Kirjandus, 10, 657-668.

Erelt, Tiiu 2007. Terminiõpetus. [Terminology.] Tartu: Tartu Ülikooli Kirjastus.

Eslon, Pille 2006. Deiktikud ja aspektisituatsioonid. - Regards multidisciplinaires sur la deixis: de l'énoncé à l'énonciation et vice-versa = Multidisciplinary Views on Deixis: from Utterance to Uttering and Vice Versa = Multidistsiplinaarsed vaated deiksisele: lausungist lausumiseni ja vastupidi. Köide 4b. Tartu: Tartu Ülikooli Kirjastus, $363-382$.

Eslon, Pille; Õim, Katre; Kaivapalu, Annekatrin; Argus, Reili; Matsak, Erika 2010. Kuidas uurida esimese ja teise keele omandamist? [Perspectives of the research of the first and of the second language acquisition.] - Lähivõrdlusi. Lähivertailuja, 20, 11-48. http://dx.doi.org/10.5128/LV20.01

Fleischman, Suzanne 1985. Discourse functions of tense-aspect oppositions in narrative: Towards a theory of grounding. - Linguistics, 23 (6), 851-882. http://dx.doi. org/10.1515/ling.1985.23.6.851

Fleischman, Suzanne 1991. Toward a theory of tense-aspect in narrative discourse. - Jadranka Gvozdanovic, Theo A. J. M. Janssen (Eds.). The Function of Tense in Texts. Amsterdam etc.: North-Holland, 75-97.

Forsyth, James 1970. A Grammar of Aspect: Usage and Meaning in the Russian Verb. Cambridge: Cambridge University Press.

Gak, Vladimir 1988. Russkij jazyk v sopostavlenii s francuzskim. [Russian Language in Comparison with the French.] Moskva.

Hrakovskij, Viktor 1985. Tipologija konstrukcij s predikatnymi aktantami. [Typology of Constructions with Clause Arguments.] Leningrad.

Hrakovskij, Viktor 1989. Tipologia iterativnyh konstrukcij. [Typology of Iterative Constructions.] Leningrad.

Hrakovskij, Viktor 1992. Tipologija imperativnyh konstrukcij. [Typology of Imperative Constructions.] Sankt-Peterburg.

Hrakovskij, Viktor 1998. Tipologija uslovnyh konstrukcij. [Typology of Conditional Constructions.] Sankt-Peterburg.

Hrakovskij, Viktor 2004. Tipologija ustupitel'nyh konstrukcij. [Typology of Concessive Constructions.] Sankt-Peterburg.

Knjazev, Jurij 2007. Grammatičeskaja semantika. Russkij jazyk v tipologičeskoj perspektive. [Grammatical Semantics. Russian in the Typological Perspective.] Moskva.

Kupp-Sazonov, Sirje 2012. Vene-eesti tõlgete mõjust eesti keele minevikuvormide kasutamisele B. Akunini mõningate teoste näitel. [Exploring the influence of RussianEstonian translations on the use of Estonian past tense forms in Boris Akunin' works.] Eesti ja soome-ugri keeleteaduse ajakiri. The Journal of Estonian and Finno-Ugric Linguistics, ESUKA / JEFUL, 3 (2), 113-128. 
Kupp-Sazonov, Sirje; Külmoja, Irina 2013. Eesti keele grammatikakategooriatest keeletüpoloogia ja kontrastiivgrammatika aspektist. - Ettekanne 12. rakenduslingvistika kevadkonverentsil 18.-19.4.2013 Tallinnas.

Lõbus, Triin; Tenjes, Silvi 2010. Narratiivi aeg ja tõlke aeg: diskursiivne käsitlus. [Time of narrative and time of translation: A discursive approach.] - Eesti Rakenduslingvistika Ühingu aastaraamat, 6, 157-174. http://dx.doi.org/10.5128/ERYa6.10

Metslang, Helle 1994. Temporal Relations in the Predicate and the Grammatical System of Estonian and Finnish. Oulu: Oulun Ylipisto.

Metslang, Helle 1997. On the use of the Estonian past tense forms through the last one hundred years. - Mati Erelt (Ed.). Estonian: typological studies II. Publications of the Department of Estonian of the University of Tartu 8. Tartu: Tartu University Press, 98-145.

Metslang, Helle 2001. Metafooridest grammatikas. [About grammatical metaphors.] - Reet Kasik (Toim.). Keele kannul: pühendusteos Mati Erelti 6o. sünnipäevaks. Tartu Ülikooli eesti keele õppetooli toimetised 17. Tartu: Tartu Ülikooli Kirjastus, 222-231.

Mihkla, Karl; Rannut, Lehte; Riikoja, Elli; Admann, Aino 1974. Eesti keele lauseõpetuse põhijooned I. Lihtlause. [Basic Characteristics of Estonian Syntax I. Simple Clause.] Tallinn: Valgus.

Mihkla, Karl; Valmis, Aavo 1979. Eesti keele süntaks kõrgkoolidele. [Estonian Syntax for Universities.] Tallinn: Valgus.

Petruhina, Elena 2009. Russkij glagol: kategorija vida i vremeni (v kontekste sovremennyh lingvističeskih issledovanij). [Russian Verb: Categories of Aspect and Tense (in the Context of Contemporary Linguistic Studies).] Moskva.

Pool, Raili; Metslang, Helle (ilmumas 2014). Jazykovye sredstva peredači vremennogo plana buduščego $\mathrm{v}$ rabotah russkih studentov na èstonskom jazyke. [Ways of Expressing Future Tense in Russian-Speaking Students' Written Papers.] - Acta Slavica Estonica. (Trudy po russkoj i slavjanskoj filologii. Lingvistika, V (XVI).

Päll jt 1962 = Pjall', Èduard; Totcel', Ėliza; Tukumcev, Gvidon. Sopostavitel'naja grammatika èstonskogo i russkogo jazyka. [Comparative Grammar of Estonian and Russian.] Tallin: Èstonskoe gosudarstvennoe izdatel'stvo.

Russkaja korpusnaja grammatika. [Russian Corpus Grammar.] http://rusgram.ru/Лицо (4.10.2013).

Serebrennikov, Boris 1963. Kategorija vremeni v pribaltijsko-finskih jazykah. - Eesti keele süntaksi küsimusi. [Questions about Estonian Syntax.] Keele ja Kirjanduse Instituudi uurimused 8. Tallinn: Eesti Riiklik Kirjastus, 426-511.

Šeljakin, Mihail 2001. Funkcional'naja grammatika russkogo jazyka. [Functional Grammar of Russian.] Moskva.

Tauli, Valter 1980. Eesti grammatika II. Lauseõpetus. [Estonian Grammar II. Syntax.] Uppsala: Finsk-ugriska institutionen.

Sirje Kupp-Sazonovi (Tartu Ülikool) peamised uurimisvaldkonnad on vene-eesti kontrastiivne grammatika, vene-eesti-vene tõlkeküsimused.

Ülikooli 17-120, 51014 Tartu, Estonia

Sirje.Kupp-Sazonov@ut.ee

Irina Külmoja (Tartu Ülikool) peamised uurimisvaldkonnad: vene keele funktsionaalgrammatika, vene-eesti kontrastiivne grammatika, eesti keele tüpoloogiauuringud, keelekontaktid, vene keel Eestis, Eesti vanausuliste keel ja kultuur.

Lossi 3-228, 50090 Tartu, Estonia

irina.kulmoja@ut.ee 


\section{ON SECONDARY USE OF GRAMMATICAL CATEGORIES: RUSSIAN AND ESTONIAN TENSE FORMS}

\section{Sirje Kupp-Sazonov, Irina Külmoja}

University of Tartu

As typological and contrastive studies of languages are becoming increasingly more important in linguistics, the need for generalised systems of grammatical categories applicable to different languages and described by a unified unambiguous terminology is acutely felt. The article focuses on secondary use of grammatical categories in Estonian and Russian. It is noted that while primary meanings of Estonian grammatical categories have already received thorough treatment, their secondary use requires further elaboration. Numerous examples of secondary use of both Estonian and Russian grammatical categories (such as number and, in particular, tense) are presented and analysed. It is shown that secondary use of grammatical categories cannot be considered marginal in either language, nor does it completely overlap in them, thus being a substantial potential source of negative transfer in language learning as well as translation and interpretation. Further contrastive linguistic study of the phenomenon is clearly required. An attempt is therefore made, proceeding from an examination of the varied terms used to designate the phenomenon in pertinent linguistic literature, to suggest a term most suitable for Estonian grammar.

Keywords: metaphor, tense, terminology, Estonian, Russian 